\title{
TARBAWI
}

Volume 4 No.1, Januari-Juni 2019

p-ISSN : 2527-4082, e-ISSN : 2622-920X

\section{Kreativitas dalam Pembelajaran}

\section{Creativity in Learning}

\author{
Abdul Aziz Muslimin'1 dan Mutakallim² \\ *1abdazizm@unismuh.ac.id |Universitas Muhammadiyah Makassar \\ *2mutakallim101161@gmail.com |Universitas Muhammadiyah Makassar
}

\begin{abstract}
Abstrak
Adapun tujuan penelitian ini yaitu untuk mengetahui kreativitas dalam pembelajaran yang dilakukan oleh dosen dan mahasiswa di program studi Pendidikan Agama Islam Universitas Muhammadiyah Makassar. Adapun metodologi penelitian yang digunakan yaitu jenis penelitiannya field research dengan metode analisis deskriptif yang bertujuan menggambarkan secara tepat inovasi dosen yang dapat merangsang kreativitas belajar mahasiswa PAI, khususnya kelas VI.A tahun akademik 2014/2015 yang menjadi sasaran penelitian. Metode pengumpulan data dilakukan dengan indepth interview atau wawancara mendalam. Adapun hasil penelitian yaitu kreativitas dalam pembelajaran menumbuhkan semangat mahasiswa dengan menerapkan sistem pembelajaran berbasis penggunaan teknologi seperti lap top dan auto fokus dalam presentasi, dosen menekankan bahwa mahasiswa harus bisa dan terampil pembuatan power. Adapun kendala-kendala dalam pembelajaran terkait media yaitu kurangnya auto fokus sebagai media yang sangat penting dan masalah teknis lainnya selama proses pembelajaran.
\end{abstract}

Kata Kunci: Kreativitas dan Pembelajaran 


\begin{abstract}
The purpose of this study is to find out the creativity in learning carried out by lecturers and students in Islamic Education Department at Muhammadiyah University of Makassar. The research methodology used is the type of research in field research with descriptive analysis methods that aim to accurately describe the innovations of lecturers who can stimulate the learning creativity of PAI students, especially VI.A class 2014/2015 academic year is the target of research. The method of data collection is done by in-depth interviews or in-depth interviews. The results of the study are creativity in learning fosters student enthusiasm by applying technology-based learning systems such as lap top and auto focus in presentations, lecturers emphasizing that students must be able and skilled in making power point. The obstacles in learning related to media are lack of auto focus as a very important medium and other technical problems during the learning process.
\end{abstract}

\title{
Keywords: Creativity and Learning
}

\section{PENDAHULUAN}

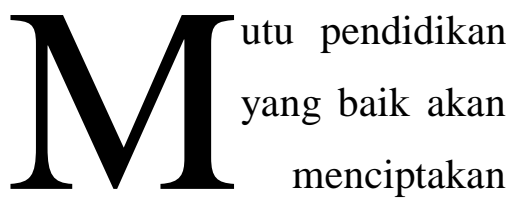

lulusan yang memiliki keterampilan hidup sehingga memiliki kemampuan untuk mengenal dan mengatasi masalah diri dan lingkungannya, dan salah satu tujuan negara Republik Indonesia adalah mencerdaskan kehidupan bangsa dan untuk itu setiap warga negara Indonesia berhak memperoleh pendidikan yang bermutu sesuai dengan minat dan bakat yang dimiliknya.

Untuk mencapai tujuan tersebut, maka setiap perguruan tinggi harus selalu meningkatkan kualitasnya, sehingga mampu menghasilkan lulusan yang mempunyai daya saing yang kuat baik di level lokal, nasional maupun internasional. Peningkatan daya saing lulusan tidak dapat ditawar-tawar karena setiap negara harus siap menghadapi globalisasi, dimana tidak ada batas antar lulusan perguruan tinggi di dunia. Jika tidak siap, maka lulusan perguruan tinggi di suatu negara tidak mampu bersaing dengan lulusan luar negeri. Untuk mampu menghasilkan lulusan bermutu tinggi, maka setiap perguruan tinggi harus memperbaiki mutu oraganisasinya serta mandiri. Dalam upaya mencapai tujuan tersebut, Ditjen Dikti mengeluarkan kebijakan baru yaitu setiap perguruan tinggi dalam pengembangannya harus mengacu kepada Higher Education Long Term Strategy (HELTS) 20032010 dan paradigma baru pengelolaan perguruan tinggi. Kebijakan Ditjen Dikti tersebut menyebutkan adanya tiga 
komponen dasar yang strategis yaitu daya saing bangsa, kesehatan organisasi dan otonomi.

Kondisi pendidikan di Indonesia mendapat sorotan dari berbagai pihak, dan seringkali kurikulum menjadi kambing hitam atas capaian pendidikan saat ini. Bahkan Inovasi Pembelajaran hampir selalu berkembang seiring dengan perkembangan ilmu pengetahuan dan kecanggihan teknologi. Kehadiran sebuah kurikulum akan berimplikasi pada dinamika baru pendidikan di Indonesia, seperti kurikulum 2013 yang sampai saat masih menuai polemik dari pemerintahan baru dan belum lagi dengan kecanggihan teknologi telah menggiring manusia hari ini ke arah pragmatisme dalam beraktivitas, termasuk dalam hal mengajar dan belajar.

Saat ini, pengaruh teknologi pada pendidikan dan pembelajaran sudah menjadi sebuah kebutuhan khususnya orang yang berkecimpung dalam bidang pendidikan. Namun, hal tersebut masih terlihat massif di kalangan guru ataupun dosen, bahkan hal ini bisa menjadi barang langka khususnya bagi mereka yang bertugas di daerah pedalaman. Di kalangan akademisi kampuspun hal ini bisa dilihat dan cukup sedikit dosen yang memanfaatkan IT/komputer untuk proses pembelajaran. Dengan demikian harus dipahami bahwa teknologi bukanlah untuk diajarkan, namun menjadi bagian yang tak terpisahkan dari konteks pembelajaran.

Masalah pendidikan yang kompleks adalah akibat dari kurikulum yang dibuat asal-asalan, lemahnya karakter bangsa, kualifikasi guru dan dosen yang rendah, dan tidak adanya perubahan mindset mengenai pendidikan. Mahasiswa selalu dituntut memiliki kompetensi, namun cukup banyak pula dosen yang tidak mengupdate metodologi pembelajaran. Mereka hanya memberikan pengetahuan tapi skill untuk meraih dan menjabarkan pengetahuan tersebut harus bisa diperagakan dan dipahami oleh peserta didik. Jadi pada dasarnya materi saja tidak cukup, karena yang dibutuhkan adalah peserta didik yang mampu menavigasi perubahan pendidikan pada masa datang.

Khusus di lembaga perguruan tinggi, keterampilan seorang tenaga pengajar ataupun dosen sangat besar pengaruhnya terhadap hasil pendidikan (out put) dan hal tersebut merupakan 
faktor yang paling dominan dalam upaya mentrasfer ilmu pengetahuan pada paserta didik, karena hal itu dapat mengatasi kebosanan mahasiswa dalam belajar, sehingga tercipta suasana belajar yang kreatif dan menyenangkan. Kreativitas perlu ditumbuhkan, dipupuk dan dikembangkan, khususnya kreativitas siswa, hal itu dapat dirangsang dengan inovasi seorang pendidik.

$$
\text { Djamarah }
$$

menekankan kemampuan seorang pendidik membangun interaksi edukatidf sehingga kreativitas melahirkan kemampuan seseorang untuk melahirkan sesuatu yang baru, baik berupa gagasan maupun karya nyata, berbentuk berfikir kreatif, dan dalam karya baru maupun kombinasi dengan hal-hal yang sudah ada. Inovasi pembelajaran berupaya menumbuhkan kreativitas belajar siswa pada tujuan utama pendidikan yaitu dengan menggunakan metode praktek, yaitu berupa aplikasi penggunaan media belajar berupa lap top yang terkoneksi ke Auto Fokus. Artinya, para mahasiswa terlebih dulu membuat power point dari substansi materti yang mereka dapatkan, selanjutnya kelompok tersebut dituntut agar dapat lebih aplikatif terhadap operasional penggunaan media tersebut.

Berdasarkan latar belakang tersebut, maka hal yang menjadi kendala adalah bagaimana dosen menumbuhkan kreativitas serta inovasi pembelajaran bagi mahasiswa, khususnya mata kuliah teknologi pembelajaran di program studi Pendidikan Agama Islam Universitas Muhammadiyah Makassar.

\section{METODE PENELITIAN}

Adapun metodologi penelitian yang digunakan yaitu jenis penelitiannya field research dengan metode analisis deskriptif yang bertujuan menggambarkan secara tepat inovasi dosen yang dapat merangsang kreativitas belajar mahasiswa PAI, khususnya kelas VI.A tahun akademik 2014/2015 yang menjadi sasaran penelitian. Metode pengumpulan data dilakukan dengan indepth interview atau wawancara mendalam. 
PEMBAHASAN

A. Data Mahasiswa dan Dosen Pengampuh Mata Kuliah semester VI Tahun Akademik 2014/2015 Program studi Pendidikan Agama Islam Universitas Muhammadiyah Makassar

\section{Tabel 1}

Data Mahasiswa Semester VI Tahun Akademik 2014/2015

\begin{tabular}{|c|c|c|c|c|}
\hline \multirow[t]{2}{*}{ No } & \multirow{2}{*}{$\begin{array}{c}\text { Mahasis } \\
\text { wa }\end{array}$} & \multicolumn{2}{|c|}{ Jenis Kelamin } & \multirow[t]{2}{*}{ Jumlah } \\
\hline & & LK & PR & \\
\hline 1 & Kelas A & 14 & 15 & 29 \\
\hline 2 & Kelas B & 10 & 17 & 27 \\
\hline 3 & Kelas C & 6 & 24 & 30 \\
\hline 4 & Kelas D & 11 & 18 & 29 \\
\hline 5 & Kelas E & 7 & 21 & 28 \\
\hline 6 & $\begin{array}{c}\text { Konvers } \\
\text { i } \\
\text { Ekstensi } \\
2012\end{array}$ & 5 & 8 & 13 \\
\hline & Total & 53 & 103 & 156 \\
\hline
\end{tabular}

Sumber :Data Simak Fakultas Agama Islam tahun ajaran 2014/2015

Dari hasil observasi terhadap data sekunder yaitu daftar Pengampuh Perkuliahan semester genap tahun akademik 2014/2015 diketahui bahwa dosen-dosen yang mengajar di semester VI berjumlah 16 orang, dan yang mengampuh mata kuliah Teknologi Pembelajaran berjumlah 3 orang. Secara umum peneliti mengamati bahwa dosen-dosen tersebut sekitar 100 persen telah berjenjang Magister (S.2) dan yang berlatar belakang pendidikan magister pendidikian 15 orang (93.75 persen).
Adapun jenjang jabatan akademik dosen yang mengajar di semester VI Tahun Ajaran 2014/2015, peneliti menemukan data sebagai berikut:

\section{Tabel 2}

Data Pangkat Akademik Dosen di semester VI

\begin{tabular}{|l|l|c|c|}
\hline No & $\begin{array}{l}\text { Pangkat } \\
\text { Akademik }\end{array}$ & $\begin{array}{c}\text { Jumlah( } \\
\text { orang) }\end{array}$ & $\begin{array}{c}\text { Persentase } \\
(\%)\end{array}$ \\
\hline 1 & $\begin{array}{l}\text { Asisten } \\
\text { Ahli }\end{array}$ & 3 & 18.75 \\
\hline 2 & Lektor & 6 & 37.5 \\
\hline 3 & $\begin{array}{l}\text { Lektor } \\
\text { Kepala }\end{array}$ & 3 & 18.75 \\
\hline 4 & $\begin{array}{l}\text { Guru } \\
\text { Besar }\end{array}$ & 0 & 0 \\
\hline 5 & $\begin{array}{l}\text { Non } \\
\text { Pangkat }\end{array}$ & 4 & 25 \\
\hline \multicolumn{2}{|l|}{ Jumlah } & 16 & 100 \\
\hline
\end{tabular}

Sumber : Hasil olah data

Data di atas menunjukkan bahwa penunjukan dosen yang mengampuh mata kuliah tidak memprioritaskan pada dosen yang telah mengantongi pangkat akademik yang menjadi patokan dasar dalam penunjukan dosen pengampuh. Fenomena tersebut bisa jadi berimplikasi pada kompetensi dan keterampilan dosen dalam penguasaan kelas ataupun penggunaan media pembelajaran. Sebagai catatan dalam olah data ini, bahwa pelibatan dosen luar biasa dalam program pengajaran ini juga harus tetap mempertimbangkan syarat-syarat dalam penunjukan dosen 
pengampuh, apalagi hampir semua dosen tetap memiliki pangkat akademik.

\section{B. Kreativitas Dosen dalam} Pembelajaran

Peneliti menelusuri lebih jauh bahwa tidak semua mata kuliah menggunakan media teknologi dalam proses pembelajaran karena dosen yang mengampuh mata kuliah tersebut tidak mendesak kepada para mahasiswa agar mereka tampil dengan penggunaan media belajar yang saat ini lagi marak digunakan dalam berbagai presentasi, yaitu pemakaian auto fokus. Bahkan metode presentasi yang diterapkan masih sangat konvensional yaitu dengan presentasi biasa, yaitu mahasiswa presentasi dengan membaca teks makalah yang telah mereka buat.

Fenomena tersebut masih sangat umum dijumpai pada beberapa kelas di program studi Pendidikan Agama Islam yang bisa jadi karena para dosen kurang kreatif dalam mendesain pembelajaran ataupun metode presentasi mahasiswa. Hal lain juga yang perlu dicermati lebih jauh yaitu bahwa tidak semua materi harus dipresentasikan, misalnya pengajaran bahasa Inggris, bahasa Arab ataupun mata kuliah yang butuh praktek langsung di lapangan karena harus lebih banyak berinteraksi dengan media konvensional yaitu papan tulis.

Salah satu metode yang telah digunakan dalam pengumpulan data ini adalah observasi, dengan mengadakan pengamatan langsung kepada mahasiswa saat presentasi di kelas ataupun menumbuhkan kreativitas belajar mahasiswa. Berdasarkan konsep-konsep dan penyajian data yang telah dipaparkan, maka secara keseluruhan kreativitas dosen pada pembelajaran mata kuliah Teknologi Pembelajaran di Prodi Pendidikan Agama Islam sudah terlaksana dengan baik, karena indikator atau prinsip-prinsip dalam kreativitas dosen di kelas sesuai .

Data yang diperoleh melalui observasi langsung di lapangan ini yang berkaitan dengan kreativitas belajar mahasiswa ini menunjukkan bahwa mahasiswa Prodi PAI kelas VI.A tampak aktif dan bersemangat dalam pembelajaran. Mereka tampak antusias mengikuti proses pembelajaran. Bahkan mereka tidak merasa malu tampil presentasi dengan hasil pembuatan Power point ataupun sekedar menjelaskan pokok bahasan di depan kelas. 
Setelah mata kuliah usai ketinggalan karena tidak memilki

(waktu istirahat), mereka masih pengetahuan tentang media dalam mendiskusikan tentang teknik proses belajar mengajar.

pembuatan power point yang barusan

Dari pengamatan peneliti, hal dipresentasikan ataupun bertanya bagaimana membuat effect. Dengan kata lain ketertarikan mahasiswa pada mata kuliah ini adalah bagaimana kemampuan mahasiswa diuji agar lebih variatif dalam presentasi sehingga menarik disimak oleh dosen dan temanteman di kelas.

Kreativitas dosen dalam pembelajaran akan sangat menentukan arah dan orientasi materi pembelajaran dapat terukur secara baik atau tidak, karena mahasiswa dapat memahami deskripsi materi ajar melalui penggunaan beragam media dalam teknologi pembelajaran. Tentunya hal ini sebagai salah satu faktor penggerak dalam pembelajaran kreatif bagi mahasiswa.

Pembelajaran kreatif pada mahasiswa sebagai kompetensi dasar dari indikator pencapaian belajar pada mahasiswa yang diharapkan dapat membawa hasil yang baik, karena dalam penerapan pembelajaran mahasiswa menjadi kritis, kreatif dan antusias walaupunn kadang kala juga ada mahasiswa yang mengalami yang perlu mendapat perhatian adalah pembentukan team teaching untuk mata kuliah yang sama sehingga tercipta irama yang sama dalam proses pembelajaran. Realitas di lapangan yaitu bahwa untuk satu mata kuliah yang diajarkan oleh beberapa dosen yang berbeda tentunya akan disampaikan dengan materi yang berbeda. Pihak program studi sudah memberikan silabus mata kuliah ataupun mengarahkan kepada kesamaan materi, namun dalam pelaksanaannya di kelas bisa jadi tidak diperhatikan lagi. Keragaman pola pengajaran pada satu materi ajar juga terlihat pada keragaman soal-soal yang masuk ke panitia ujian akhir semester.

\section{Inovasi \\ Pembelajaran Pembelajan}

Di kelas VI.A, dosen mengawali pertemuan dengan penjelasan, maksud dan tujuan mata kuliah serta beberapa penjelasan lainnya. Penjelasan tersebut berlanjut hingga ke pertemuan ke-3. Nanti pertemuan ke-4 barulah mahasiswa diberi kesempatan melakukan inovasi 
pembelajaran, berikut bahasan lengkapnya.

\section{Penyajian Materi}

Berikut ini wawancara salah seorang informan kelas VI. A, Candra bahwa:

"Dosen Mata Kuliah Teknologi Pembelajaran melakukan pengembagan materi dengan menekankan mahasiswa bahwa presentasi harus dengan power point, namun sebelum itu beliau mengajar kami terlebih dulu diajarkan tata cara pembuatan power point sehingga dari situlah sebagian teman-teman mengembangkan....dan memang ada juga teman-teman yang sebelumnya sudah tahu program tersebut. (wawancara, 18 Agustus 2015).

Dalam pelaksanaannya, dosen memberikan kebebasan kepada para mahasiswa/kelompok yang akan tampil untuk berimprovisasi dengan tayangan slide yang akan mereka tampilkan nantinya sebagai bentuk kreativirtas mereka. Hal ini digunakan agar supaya mahasiswa tidak mengalami kejenuhan ataupun kebosanan dalam pembelajaran di kelas, karena kebanyakan dosen hanya menerapkan metode ceramah ataupun presentasi manual yang dosennya hanya datang, duduk dan absensi yang membuat kejenuhan bagi mahasiwa dan akan menjadi penghambat dalam proses

pembelajaran. Tentunya dengan pengamatan yang tepat dan konsisten dari dosen yang bersangkutan sehingga mahasiswa di kelas akan mampu menumbuhkan nilai-nilai kreativitas secara luas menurut kemampuan pola pikir mahasiswa tersebut.

Penilaian yang hampir senada dikemukakan oleh Syamsul Bahri, Ketua kelas VI.A bahwa:

Kompetensi dosen yang mengajarkan mata kuliah ini cukup baik, sehingga kami mahasiwa tertantang untuk tampil dengan gaya presentasi yang beliau inginkan yaitu membuat power point. Namun kendala dalam pembelajaran mata kuliah ini yaitu penekanan oleh dosen yang bersangkutan khususnya bagi pemakalah agar kreatif meminjam auto fokus di Prodi Pendidikan Agama Islam padahal saat yang bersamaan ada juga kelas lain yang membutuhkan.....semoga ini menjadi perhatian pimpinan. (wawancara, 18 Agustus 2015).

Deskripsi wawancara di atas menunjukkan bahwa inovasi seorang dosen dalam pembelajaran di kelas akan sangat menentukan pola pembelajaran bagi mahasiswa. Di sisi lain keterbatasan media auto fokus menjadi tantangan tersendiri karena harus melewati perjuangan yang cukup berat agar mereka bisa 
mendapatkan pada waktu yang bersamaan dengan kelas lain.

\section{Pelaksanaan kreativitas}

dosen teknologi pembelajaran yang berpengaruh pada kreativitas belajar mahasiswa sehingga seorang dosen harus mengetahui dan menggunakan beberapa sistem pengajaran yang menggunakan beberapa metode yang mendukung untuk mendapatkan suatu sisi keberhasilan dan kemudahan dalam pembelajaran yang kreatif bagi mahasiswa. berikut wawancara dengan Bapak Ahmad Abdullah, S.Ag, M.Pd. salah seorang dosen Mata Kuliah teknologi Pembelajaran:

"Pengajaran mata kuliah ini harus komprehensif, artinya dosen harus terampil mengajarkan kepada para mahasiswa beragam teknologi pembelajaran dan pemanfaatannya dalam seminar kelas. Bukan hanya memperkenalkan beragamn jenis teknologi dalam pendididkan tapi harus aplikatif'. (wawancara tanggal 20 Agustus 2015)

Selanjutnya dalam penerapan

metode tersebut mahasiswa akan merasakan suatu kegembiraan serta membawa hasil yang maksimal bagi mahasiswa. Karena dengan kreativitas dosen tentunya banyak mengandung pola belajar kreatif dan menyenangkan dengan menghandalkan kreativitas mahasiswa dan sebuah langkah positif dari dosen, yaitu dengan memadukan, menjelaskan, mempraktekkan dan sebagainnya yang berkenaan dengan kreativitas dosen tersebut tentunya.tidak lepas dari sebuah pengawasan dari dosen mata kuliah yang lebih mengedepankan 3 ranah psikologis mahasiswa, yaitu kognitif, afektif dan psikomotorik.

Sebagaimana tujuan dari penelitian ini yaitu untuk mengetahui bentuk kreativitas dosen untuk, menumbuhkan kreativitas belajar mahasiswa pada Mata Kuliah Teknologi Pembelajaran dalam menumbuhkan kreativitas belajar mahasiswa, maka peneliti menganalisa data sebagai berikut:

\section{Kreativitas Belajar}

\section{Mahasiswa}

Proses belajar akan berlangsung menarik bilamana terjadinya sinergitas antara pengajar dan pebelajar dalam suatu waktu. Perilaku seorang pengajar di kelas tentunya akan sangat memberikan daya kreasi kepada para mahasiswa. Berikut Wawancara dengan Wardah, mahasiswi kelas VI.a

"Pak...cara dosen mengajar akan sangat mempengaruhi kami dalam belajar di kelas. ada dosen yang 
kreatif dalam mengajar, namun ada juga dosen yang cuma tahu suruh pemakalah tampil dan dia cuma dengar-dengar diskusi lalu absent dan pulang". (wawancara, 9 Juli 2015)

Komentar senada juga dikemukakan oleh Nasruddin, mahasiswa kelas VI.a bahwa:

"yah memang kami tergantung dari dosen yang mengajar, sehingga kami kreatif......tapi itu mungkin saya karena biasanya terlambat dan saya juga bekerja. Tapi pada dasarnya kreativitas mahasiswa sangat tergantung dari pengajar di kelas/ dosen". (wawancara, 9 Juli 2015)

Dari hasil wawancara di atas, peneliti menarik kesimpulan bahwa kreativitas pebelajar/ mahasiswa akan sangat tergantung dari pola dan cara mengajar seorang dosen. Namun demikian mahasiwa juga harus berani tampil lebih Powerfiull dalam setiap aktivitas belajarnya, jangan cuma demonstrasi yang ok tapi juga harus bisa menerjemahkan keterbatasan yang diberikan di kelas kepada pola pembelajaran yang lebih inovatif dan kreatif. Peneliti melihat ini sebagai sebuah keharusan karena kecanggihan teknologi hari ini sudah tanpa batas, dimana seseorang bisa jadi lebih mahir dan paham akan sebuah metode ataupun masalah karena perangkat "OM
GOGGLE" sudah menjadi pemberi informasi bagi siapa yang melacaknya, termasuk di kelas yang bisa jadi mahasiswa lebih terampil dari dosennya bila para dosen tidak berpikir untuk mengembangkan diri.

Untuk dapat merencanakan proses pembelajaran secara inovatif yang mampu memberikan pengalaman yang berguna bagi mahasiswa, kita perlu memperlihatkan komponen penting proses pembelajaran. Dari komponen proses pembelajaran tersebut, dosen dapat merencanakan kegiatan dan strategi pembelajaran yang relevan dengan tujuan belajar. Seorang dosen tentunya tidak hanya mengusahakan bagaimana metode pembelajaran yang dia terapkan berhasil yang tercermin dari nilai-nilai mata pelajaran, tapi bagaimana mempengaruhi mahasiswanya untuk mau belajar.

Pembelajaran inovatif dilakukan untuk mengoptimalkan pencpaian semua hasil belajar dan mengakomodasi sebanyak-banyaknya perbedaan mahasiswa. Dengan demikian, implementasi pembelajaran inovatif selalu multimetode, multimedia, berpusat pada mahasiswa,dilakukan secara alami dan 
memberikan peluang mahasiswa mengalami sendiri.

Untuk dapat merencanakan proses pembelajaran secara inovatif yang mampu memberikan pengalaman yang berguna bagi mahasiswa, kita perlu memperhatikan komponen penting proses pembelajaran. Dari komponen proses pembelajaran tersebut dosen dapat merencanakan kegiatan dan strategi pembelajaran yang relevan dengan tujuan belajar.

Proses belajar yang baik di awali dengan adanya motivasi, jika motivasi tidak ada pada mahasiswa, sulit akan diharapkan terjadi proses belajar dalam diri mereka. Dari motivasi ini muncul kreatifitas dengan harapan-harapan yang tinggi. Oleh sebab itu, tugas utama dosen dalam melakukan inovasi pembelajaran untuk menjamin terjadinya hasil belajar yang optimal pada mahasiswa ialah menghidupkan motivasi belajar mahasiswa.

\section{Mengenai Kreativitas} mahasiswa kita ketahui bahwa berpikir lebih kreatif dan inovatif dalam menghadapi permasalahan dan situasi tidak akan dimiliki tanpa adanya pengetahuan yang luas. Maka dari merupakan tuntutan terhadap mahasiswa untuk mampu berpikir lebih kreatif lagi.

Proses kreatif mahasiswa tersebut tentunya tidak akan dapat dilaksanakan tanpa adanya pengetahuan yang didapat melalui membaca, berbahasa, dan aspek-aspek lain. Oleh sebab itu seorang mahasiswa di tuntut dapat mengembangkan atau menumbuhkan pola pikirnya untuk lebih kreatif. Hal ini menunjukkan bahwa proses mahasiswa telah menyelesaikan suatu proses pembelajaran dan pengembangan pemikiran dengan baik dan membuktikan bahwa strategi belajar yang di pilihnya sudah tepat dan berhasil.

Kreativitas adalah salah satu kunci yang perlu dilakukan dosen untuk memberikan layanan pendidikan yang maksimal sesuai kemampuan dan keahlian khusus dalam bidang keilmuan. Guna menumbuhkan kreativitas belajar para mahasiswa maka dosen di tuntut lebih kreatid dalam mengajar, dosen juga di tuntut untuk lebih kreatif dalam proses pembelajaran di sekolah karena di masa mendatang dosen tidak lagi menjadi satu-satunya orang yang paling pintar di tengah-tengah mahasiswanya. 


\section{Kendala Dosen dalam}

Menumbuhkan Kreativitas

\section{Belajar}

Mata kuliah teknologi pembelajaran adalah sebuah mata kuliah yang dituntut untuk bagaimana memadukan sebuah materi dengan perangkat pembelajaran di kelas. Substansinya bisa memadukan pengajaran media belajar dan metode mengajar, sehingga seorang dosen dituntut untuk lebih siap dengan proses pembelajaran yang terjadwal. Namun dalam prosesnya terdapat beberapa variabel yang bisa menjadi penghambat terhadap berjalannya proses tersebut secara baik.

Berikut wawancara peneliti dengan Sekretaris Prodi PAI, Dr. Hj. Maryam, M.Th.I bahwa:

"Secara umum pelaksanaan perkuliahan di Prodi PAI berjalan lancar, namun banyak juga dosen yang senantiasa mengembangkan pembelajaran dengan penggunaan auto fokus supaya lebih kreatif dan materi bisa disederhanakan. Kendala kami adalah keterbatasan auto fokus dalam proses pembelajaran jika semua membutuhkan pada jam yang bersamaan, padahal di prodi PAI terdapat cuma 3 unit auto fokus". (wawancara, 2 September 2015)

Dari wawancara di atas cukup jelas dipahami bahwa perangkat pembelajaran yang satu ini sangat terbatas dibandingkan dengan jumlah kelas prodi PAI sebanyak 29 rombongan belajar dengan ketersediaan jumlah kelas sebanyak 12 ruangan. Namun kendala lain dari hasil observasi peneliti yaitu karena tidak terpasangnnya secara permanen auto fokus di kelas, yang bila dosen akan mengajar barulah mahasiswa pergi mencari ke kantor Prodi PAI dan itupun kalau tidak didahului oleh kelas lain. Belum lagi persoalan kabel yang kadang bermasalah, jadi idealnya semua ruangan belajar terpasang satu unit Auto Fokus. Namun bila ini juga diterapkan kekhawatiran baru muncul yaitu masalah keamanan auto fokus di ruang kelas, karena banyak pihak yang selalu berprinsip "rasa memilikinya terlalu tinggi" alias bisa hilang.

Fenomena lain, yaitu saat-saat tertentu colokan-colokan listrik di kelas terkadang di-off-kan oleh instalator dan pada ruangan lain tetap berfungsi, khususnya di lantai 4 gedung Iqra ternyata sekitar 7 kelas tidak berfungsi dari 12 kelas khusus untuk Fakultas Agama Islam. Dari penelusuran peneliti terhadap beberapa pekerja diketahui bahwa ada upaya penghematan listrik karena saat itu Lift 
mulai difungsikan sehingga bila saat bersamaan banyak pemakaian tenaga listrik, maka lift tidak bisa maksimal.

Adapun kendala lain, yaitu prodi ataupun pimpinan fakuktas tidak mengusulkan dalam Rapat Kerja untuk peningkatan Sumber Daya Dosen FAI dengan program kegiatan Workshop pembelajaran dosen, Workshop Penelitian Dosen atau Lesson Study. Dengan keterampilan yang ada para dosen berupaya semaksimal mungkin melakukan transformasi ilmu kepada para mahasiswa yang bisa jadi mereka sudah ketinggalan dengan percepatan pembangunan dan terknologi saat ini.

\section{PENUTUP}

1. Inovasi dosen yang dilakukan sebagai upaya menumbuhkan kreativitas mahasiswa yaitu dengan menerapkan sistem pembelajaran berbasis penggunaan teknologi, misalnya penggunaan lap top dan Auto Fokus dalam proses belajar mengajar. Metode ini akan saling memberikan pengaruh kepada para dosen juga untuk bisa dan terampil dalam penggunaan teknologi pembelajaran
2. Dosen mata kuliah tenologi pembelajaran menekankan bahwa mahasiswa harus bisa dan terampil terhadap penggunaan berbagai media pembelajaran serta pembuatan power point. Khusus, saat presentasi makalah sangat ditekankan menggunakan power poin sebagai sebuah pembiasaan penggunaaan teknologi dalam proses belajar mengajar.

3. Mahasiwa akaq kreatif dengan pembuatan power poin disertai animasi-animasi tampilan yang cukup memukau. Semoga menjadi bekal dasar mereka sehingga lebih siap menghadapi jenjang pendidikan lanjut yang serba dengan penggunaan teknologi dalam belajar.

4. Sesuai dengan hasil penelitian disarankan agar ada pelatihanpelatihan dosen ditingkat fakultas sebagai upaya memacu Sumber Daya Mansusia para pengajarnya.

\section{DAFTAR PUSTAKA}

Djamarah,Syaiful Bahri, 2000, Guru dan Anak Didik Dalam Interaksi Edukatif, Jakarta: Rineka Cipta.

Haamalik, 1992. Etika Islam Tentang Kenakalan Remaja. Cet. II; Jakarta: Rineka Cipta. 
Mulyadi, 1998, Kemampuan Dasar Guru dalam Proses Belajar Mengajar, Bandung: Remaja Rosdakarya.

Slameto, 1995, Belajar dan Faktorfaktor yang Mempengaruhinya, Jakarta, Rineka Cipta.

Suwarna, 2005. Mengajar dalam pendidikan, Cet. V; Jakarta: RajaGrafindo Persada.
Utami,Munandar.

1999, Pengembangan Kreatifitas Anak Berbakat, Jakarta, Rineka Cipta.

UU nomor 14 Tahun 2005 tentang Guru dan Dosen

UU Nomor 20 tahun 2003 tentang Sistem pendidikan Nasional 